\title{
Problematyka bezpieczeństwa wewnętrznego w programach polskich partii politycznych po 1989 roku
}

\section{Internal Security Issues in Programmes of Polish Political Parties after 1989}

\section{- Abstrakt •}

Choć bezpieczeństwo jest podstawową potrzebą zarówno jednostki, jak i organizacji państwowych, w programach polskich partii politycznych po 1989 roku pojawiało się stosunkowo rzadko, zwłaszcza w swoim wąskim rozumieniu. Zmianę w tym trendzie obserwujemy dopiero w połowie drugiej dekady XXI wieku, nie ma jednak pewności, czy będzie ona trwała. Artykuł ma na celu prezentację zagadnień z zakresu bezpieczeństwa wewnętrznego obecnych $\mathrm{w}$ programach polskich partii politycznych w III Rzeczypospolitej oraz ich jakościową analizę.

Słowa kluczowe: bezpieczeństwo wewnętrzne, polityka bezpieczeństwa, partie polityczne

\section{- Abstract •}

Although safety is a basic personal and institutional need, its presence in programmes of Polish political parties is not impressive. We can observe a change in the second decade of the $21^{\text {st }}$ century, but there is no certainty how constant is it. The article aims to present internal security issues in programmes of Polish political parties during the period of the Third Republic and their qualitative analysis.

Keywords: internal security, security policy, political parties

\section{Wprowadzenie}

Polska polityka bezpieczeństwa po 1989 roku doczekała się wielu opracowań. Warto tu wspomnieć chociażby traktujące problematykę całościowo prace autorstwa R. Zięby (1997, 2004, 2013 i inne), J. Kukułki (2001), J. Czaputowicza (2013, 2014) lub S. Kozieja (1996, 2001, 2005, 2006, 2009), oraz opracowania poświęcone wybranym aspektom tej polityki; chociażby R. Kupiecki o procesie wejścia Polski do NATO (2014) i projekcie umieszczenia tarczy antyrakietowej (2015) 
czy J.M. Fiszer (2006, 2009, 2011) o aspektach bezpieczeństwa związanych z integracją europejską. Większość z nich skupia się jednak na polityce bezpieczeństwa rozumianej przede wszystkim jako element polityki zagranicznej państwa, bądź na aspekcie stricte militarnym ${ }^{1}$. Autorce natomiast bliższe jest podejście całościowe, rozumiejące politykę bezpieczeństwa jako „element polityki państwa w zakresie praktycznej działalności władzy wykonawczej w aspekcie tworzenia, wykorzystania i utrzymania wszechstronnego potencjału państwa, w poszczególnych, przedmiotowych sferach bezpieczeństwa państwa” (Ciszek, 2011), w tym również bezpieczeństwa wewnętrznego.

Celem niniejszego artykułu jest przedstawienie zarysu problematyki bezpieczeństwa wewnętrznego, ujętej w programach polskich partii politycznych po 1989 roku, w wybranych przez autorkę aspektach. Ogrom materiału zebrany w wyniku wstępnej kwerendy danych, wymuszał konieczność zawężenia dalszej analizy do wybranych problemów z zakresu bezpieczeństwa państwa. Ich lista zostanie zaprezentowana w dalszej części artykułu. Aby zebrać materiał badawczy, przeanalizowano oficjalne programy partii politycznych biorących udział w wyborach:

- parlamentarnych, z lat: 1989, 1991, 1993, 1997, 2001, 2005, 2007, 2011, 2015;

- prezydenckich, z lat: 1990, 1995, 2000, 2005, 2010, 2015.

Analizie poddano dokumenty oficjalne, deklaracje programowe, manifesty wyborcze. Nie analizowano wystąpień poszczególnych polityków ani wywiadów prasowych czy telewizyjnych. Założenie bowiem opierało się na przekonaniu, że kluczowe jest zbadanie, co poszczególne ugrupowania oraz wysuwani przez nich kandydaci mają do zaproponowania w obszarze bezpieczeństwa publicznego sami z siebie, a nie dopiero wtedy, gdy zostaną o to zapytani, w tym na ile te kwestie są istotne $\mathrm{w}$ porównaniu $\mathrm{z}$ innymi poruszanymi w czasie kampanii zagadnieniami.

\section{Kwestie definicyjne. Bezpieczeństwo wewnętrzne a bezpieczeństwo publiczne i bezpieczeństwo powszechne}

Choć zazwyczaj przyjmuje się, że bezpieczeństwo wewnętrzne to stan struktur politycznych, społecznych i ekonomicznych, który zaspokaja potrzeby i aspira-

1 W aspekcie stricte militarnym podkreśla się, iż polityka bezpieczeństwa stanowi „element polityki państwa w zakresie praktycznej działalności władzy wykonawczej w sferze tworzenia i wykorzystania potencjału obronnego dla realizacji celów i zadań wynikających z założeń polityki bezpieczeństwa. Stownik podstawowych terminów bezpieczeństwa państwa 1994. 
cje państwa oraz jego obywateli, w literaturze przedmiotu trudno znaleźć więcej niż jedną powszechnie uznaną definicję; funkcjonuje również wiele określeń tego zjawiska. Dyskurs na temat granic przedmiotowych i podmiotowych bezpieczeństwa wewnętrznego nigdy nie został bowiem jednoznacznie rozstrzygnięty (Smith, 2006). Jak zauważa A. Sekściński (2013), odwołując się do S. Sulkowskiego (2011), problem ten występuje nie tylko w Polsce, ale i w innych krajach. Wystarczy przyjrzeć się nazewnictwu zjawiska - w języku angielskim są to: internal security, domestic security, civil defence, homeland security, societal security, civil emergencies, w języku niemieckim: innere Sicherheit i öffentliche Sicherheit, $\mathrm{w}$ języku francuskim: securite interieure i securite publique, we włoskim: sicurezza interna i sicurezza pubblica, hiszpańskim: seguridad interior i seguridad publica. Jak widać, nie tylko w Polsce termin bezpieczeństwo wewnętrzne jest często stosowany zamiennie z bezpieczeństwem publicznym bądź bezpieczeństwem powszechnym, choć większość badaczy zjawiska uważa, że nie są one z bezpieczeństwem wewnętrznym tożsame. Bywają natomiast jego składowymi bądź mają z nim istotne części wspólne. Nie wchodząc w te spory, warto dokonać krótkiego przeglądu definicyjnego wspomnianych rodzajów bezpieczeństwa. Wybór definicji wszystkich trzech pojęć prezentuje tabela 1 .

Tabela 1. Wybrane definicje pojęć: bezpieczeństwo publiczne, bezpieczeństwo powszechne i bezpieczeństwo wewnętrzne państwa

\section{Bezpieczeństwo publiczne}

1. Stan wewnątrz państwa, który umożliwia normalne funkcjonowanie organizacji państwowej i realizacje jej interesów, zachowanie życia, zdrowia i mienia jednostek żyjących w tej organizacji (nie tylko obywateli) oraz korzystanie przez te jednostki z praw i swobód zagwarantowanych konstytucją i innymi przepisami prawa (Zaborowski, 1985);

2. Utrzymanie zdolności do reagowania w przypadku wystąpienia zagrożeń bezpieczeństwa publicznego oraz bezpieczeństwa powszechnego, związanych z ochroną porządku prawnego, życia i zdrowia obywateli oraz majątku narodowego przed bezprawnymi działaniami oraz skutkami klęsk żywiołowych, katastrof naturalnych i awarii technicznych (Fleischner, von Hippel, Barton, 2009).

\section{Bezpieczeństwo powszechne}

Najczęściej opisuje się je jako stan zapewniający ochronę życia i zdrowia obywateli oraz majątku narodowego przed skutkami klęsk żywiołowych i katastrof technicznych. (...) Przedmiotem zainteresowania bezpieczeństwa powszechnego są przede wszystkim stany zagrożenia jednostek i grup społecznych, na które oddziałują zmiany w środowisku naturalnym (Sekściński, 2014). 
Tab. $1-\mathrm{cd}$.

\section{Bezpieczeństwo wewnętrzne}

1. Obejmuje ogół przedsięwzięć podejmowanych przez administrację publiczną w formie polityki regulacyjnej i działań planistyczno-organizacyjnych w celu zapewnienia społeczeństwu odpowiedniego poziomu bezpieczeństwa i szybkiej pomocy w przypadku wystąpienia określonego zagrożenia (Strategia Bezpieczeństwa Narodowego, 2014);

2. Szerokie i kompleksowe pojęcie, łączące wiele sektorów, mające stanowić odpowiedź na wspomniane i inne poważne zagrożenia (w tym klęski żywiołowe i antropogeniczne, takie jak pożary lasów, trzęsienia ziemi, powodzie i wichury), które mają bezpośredni wpływ na życie, bezpieczeństwo i komfort obywateli (Strategia bezpieczeństwa wewnętrznego UE, 2010);

4. Przez działania państwa na rzecz bezpieczeństwa wewnętrznego należy rozumieć działania podejmowane przez właściwe organy decyzyjne, służące zapewnieniu (za pomocą odpowiednich środków) bezpieczeństwa publicznego, a więc osiągnięciu zamierzonego celu, którym jest utrzymanie spokoju i normalności zachowań w społeczeństwie (Wawrzyk, 2009);

5. Ujmowane w sensie uniwersalnym - należy wiązać ze stanem niezakłóconego funkcjonowania państwa, związanym z bezpieczeństwem jego organów oraz stabilnością życia społecznego, wynikającą z bezpieczeństwa osobistego i bezpieczeństwa egzystencji jego obywateli (Majer, 2012);

6. Taki stan funkcjonowania państwa, który zapewnia przeciwdziałanie, eliminowanie lub ograniczanie zagrożeń dla ustroju konstytucyjnego, porządku wewnętrznego i spokoju oraz umożliwia ochronę interesu publicznego poszczególnych społeczności i każdego obywatela (Wojtaszczyk, 2009).

Źródło: opracowanie własne.

$\mathrm{Na}$ potrzeby niniejszego artykułu stosowana będzie definicja bezpieczeństwa wewnętrznego autorstwa B. Wiśniewskiego, w której bezpieczeństwo publiczne i powszechne są częściami składowymi bezpieczeństwa wewnętrznego, a ono samo jest definiowane jako „stan uzyskany w efekcie spełniania przez państwo funkcji wewnętrznej realizowanej w ramach strategicznej polityki bezpieczeństwa narodowego, przejawiający się ochroną:

- w ujęciu wąskim - porządku konstytucyjnego, bezpieczeństwa publicznego i bezpieczeństwa powszechnego;

- w ujęciu szerokim - porządku konstytucyjnego, życia i zdrowia obywateli, majątku narodowego przed bezprawnymi działaniami, a także skutkami klęsk żywiołowych i katastrof technicznych" (Wiśniewski, 2002, za: Majer, 2012) 


\section{System partyjny i wybory w III RP. Zarys problemu}

W wyniku ustaleń Okrągłego Stołu w 1989 roku odbyły się pierwsze, częściowo wolne wybory parlamentarne. Trudno w ich przypadku mówić o systemie partyjnym: naprzeciwko PZPR, ZSL i SD stanęła strona „Solidarnościowa” zorganizowana w Komitet Obywatelski przy Lechu Wałęsie. Kandydaci wspierani przez KO zdobyli wszystkie mandaty przeznaczone dla bezpartyjnych (35\%, 161 miejsc), a także objęli 99\% miejsc w Senacie. W tym samym roku prezydentem RP wybranym przez Zgromadzenie Narodowe został gen. Wojciech Jaruzelski. Kampania miała charakter czysko wizerunkowy - Solidarność promowała swoich kandydatów wspólnymi zdjęciami z liderem „Solidarności”, a kandydaci partii rządzących starali się ukazać jako reformatorzy. Głosowano na organizacje, nie ludzi.

Oczywiste było, że kontraktowy parlament i prezydent nie dotrwają do końca ustawowych kadencji. Jak wskazują chociażby Juan J. Linz i Alfred Stepan, w toku realizacji przejścia do demokracji powstaje rząd, który zawsze ma charakter przejściowy (prowizoryczny), a jego głównym zadaniem jest doprowadzenie do wolnych wyborów parlamentarnych (Linz, Stepan, 1996). Pierwsze wolne wybory parlamentarne i prezydenckie odbyły się odpowiednio w 1991 i 1990 roku. Po raz pierwszy Polacy wybierali prezydenta w wyborach bezpośrednich. Został nim Lech Wałęsa, który konkurował nie tylko z przedstawicielem postkomunistów, ale również z dwoma kandydatami ze swojego obozu (Tadeuszem Mazowieckim i Janem Olszewskim). W wyborach parlamentarnych, przy braku progów wyborczych do Sejmu i 43\% frekwencji, do izby niższej weszło 29 ugrupowań. Największe z nich miały po 60 mandatów. To właśnie rozdrobnienie, przepisy tzw. Małej Konstytucji dające prezydentowi duży wpływ na kształtowanie rządu i kłótnie w obozie solidarnościowym doprowadziły do przyspieszonych wyborów w 1993 roku. Uchwalona w maju tego roku nowa ordynacja wyborcza nie tylko wprowadzała 5-procentowy próg wyborczy, ale również - przez wprowadzenie metody d’Hondta przy liczeniu głosów - działała na korzyść większych partii bądź ich koalicji (Słodkowska, 2001). Wygrał w nich Sojusz Lewicy Demokratycznej, który zawiązał koalicję z Polskim Stronnictwem Ludowym. Była to pierwsza pełna kadencja polskiego parlamentu po 1989 roku. Kolejne wybory prezydenckie (1995) wygrywa Aleksander Kwaśniewski, pokonując nie tylko Lecha Wałęsę, ale i innych z 15 pozostałych kandydatów.

Wybory parlamentarne z 1997 roku były pierwszymi, w których można było obserwować konkurencję programów wyborczych. Jak zauważa Inka Skłodowska, dwie wcześniejsze elekcje charakteryzowały się brakiem skrystalizowanych, odnoszących się do wszystkich dziedzin funkcjonowania państwa programów wy- 
borczych. Przeważały obszerne, nieusystematyzowane materiały bądź partie podejmujące jedną kwestię. Kampania roku 1997 po raz pierwszy pokazała znaczenie tego dokumentu - oficjalnie prezentowanego, drukowanego w atrakcyjnej formie i poddanego konfrontacji z propozycjami przeciwników. (Słodkowska, Dołbakowska, 2004) Można więc uznać, że jest to czas, gdy w Polsce zaczynamy mówić o w pełni funkcjonującym demokratycznym systemie politycznym (Ziółkowski, 2000). Wybory te wygrywa Akcja Wyborcza „Solidarność” (33,8\% głosów), o 7\% mniej zdobywa SLD. Rok 2000 to reelekcja prezydencka Aleksandra Kwaśniewskiego w I turze. W 2001 kolejny wybory parlamentarne wygrywa lewica i ponownie do władzy dochodzi koalicja SLD-PSL. Toczona przed tymi wyborami kampania w jeszcze większym niż w 1997 roku staje się starciem programów, przy czym zauważalne jest ich objętościowe ograniczanie. Trudno jeszcze mówić o sprowadzaniu ich do haseł nie dłuższych niż 200 znaków (to będzie zauważalne w kampaniach w XXI wieku), ale widać już zauważalną dbałość o formę i treść prezentowanych dokumentów. Wybory te są pierwszymi, podczas których nie istnieje już lista krajowa.

Rok 2005 to czas podwójnej kampanii prezydenckiej i parlamentarnej, które wygrywa Lech Kaczyński oraz Prawo i Sprawiedliwość. Po raz pierwszy od 1989 roku w kampanii wyborczej nie mamy do czynienia z dychotomią: postkomuna - post-Solidarność. Zarówno PiS, jak i jego największy rywal - Platforma Obywatelska - mają w zdecydowanej większości rodowód postsolidarnościowy. Podział rysuje się na nowej linii - Polska solidarna versus Polska liberalna. Są to również pierwsze tak spersonifikowane wybory (starcia liderów, nie partii). Kolejne, przyspieszone wybory parlamentarne z 2007 roku w tej kwestii nic nie zmieniają - starcie staje się jeszcze bardziej spersonifikowane, a tropienie nieścisłości w programach wyborczych rywali - główną strategią na pokonanie oponenta. To starcie wygrywa PO, które wspólnie z PSL współtworzy przez cztery lata rząd. Przyspieszone wybory prezydenckie z 2010 roku odbywają się w cieniu katastrofy smoleńskiej. Związany z nią ostry konflikt polityczny będzie od tej pory wyznacznikiem kolejnych kampanii wyborczych i przyczyni się do jej dalszej personalizacji, a w konsekwencji do nowego ostrego podziału elektoratu. Odbywające się rok później wybory parlamentarne, które po raz drugi z rzędu wygrywa Platforma Obywatelska, umocnią tylko tę tendencję. Podobnie jak 4 lata wcześniej do parlamentu wystawi listy 11 ugrupowań (w 2007 roku - 10), a dwa zwycięskie ugrupowania zgarną 69\% głosów i 79\% wszystkich mandatów. Jak wskazuje Jacek Raciborski, na przestrzeni tego czasu mamy do czynienia z systemem umiarkowanie wielopartyjnym, z tendencją do dwupartyjnego (Raciborski, 2013). Kolejne podwójne wybory prezydenckie i parlamentarne z 2015 roku będą należały po- 
nownie do Prawa i Sprawiedliwości oraz jego kandydata na prezydenta (Andrzeja Dudy). W kontekście systemu partyjnego możemy mówić o dalszej konsolidacji i grawitowaniu w kierunku dwupartyjności, z silnym elementem personifikacji. Będzie to natomiast bez wątpienia pierwsza kampania wyborcza, w której tak wiele miejsca w programach partii i kandydatów poświęcone zostanie kwestiom bezpieczeństwa.

\section{Wybrane zagadnienia bezpieczeństwa wewnętrznego w programach polskich partii politycznych}

Przed przejściem do przedstawienia elementów programów partii politycznych związanych z bezpieczeństwem wewnętrznym państwa zauważyć należy, że bezpieczeństwo w ogóle w skali analizowanego okresu nie było kwestią szczególnie często poruszaną w programach polskich partii politycznych. W przeprowadzonej przez Mikołaja Cześnika w 2011 roku analizie ilościowej tychże programów z lat 2001-2007 widać wyraźnie, że kwestie prawa i porządku (kategoria stworzona przez autora, najbliższa tematyce bezpieczeństwa wewnętrznego) są istotne tylko dla części ugrupowań (Cześnik, 2011). Wybrane wyniki tych badań prezentuje tabela 2 .

Tabela 2. Obecność zagadnień związanych z bezpieczeństwem wewnętrznym w programach czterech głównych partii w wyborach parlamentarnych z lat 2001-2007

\begin{tabular}{|c|c|c|c|c|c|c|c|c|}
\hline \multirow[b]{2}{*}{ 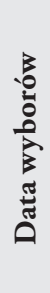 } & \multicolumn{2}{|c|}{ SLD/LiD } & \multicolumn{2}{|c|}{ PO } & \multicolumn{2}{|c|}{ PiS } & \multicolumn{2}{|c|}{ PSL } \\
\hline & 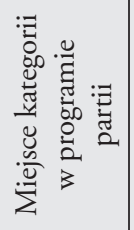 & 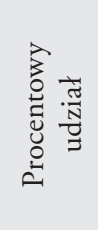 & 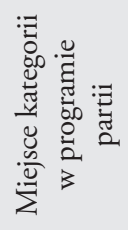 & 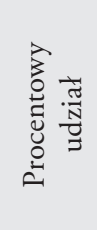 & 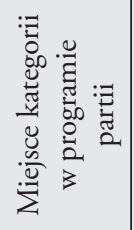 & 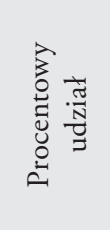 & 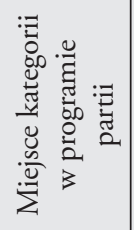 & 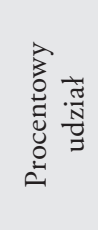 \\
\hline ¿্் & $6 / 10$ & $6,52 \%$ & $6 / 10$ & $7,15 \%$ & $3 / 10$ & $11,09 \%$ & $10 / 10$ & $1,71 \%$ \\
\hline ڤै & brak & brak & $8 / 10$ & $6,64 \%$ & $5 / 10$ & $6,39 \%$ & brak & brak \\
\hline હิ & brak & brak & brak & brak & $5 / 10$ & $8,19 \%$ & $10 / 10$ & $4,05 \%$ \\
\hline
\end{tabular}

Źródło: opracowanie własne, na podstawie: Cześnik, 2011. 
Jak wspomniano we wprowadzeniu, po wstępnej analizie zebranych danych dokonano wyboru zagadnień z zakresu bezpieczeństwa wewnętrznego, które zostały następnie poddane szczegółowej analizie. Ich zestawienie zawiera tabela 3.

Tabela 3. Zagadnienia bezpieczeństwa wewnętrznego poddane analizie

\begin{tabular}{|c|c|}
\hline $\begin{array}{l}\text { Dziedzina bezpieczeństwa } \\
\text { wewnętrznego }\end{array}$ & Podnoszone kwestie szczegółowe \\
\hline $\begin{array}{c}\text { Transformacja, } \\
\text { organizacja, system } \\
\text { dowodzenia } \\
\text { i kierowania } \\
\text { formacjami policyjnymi }\end{array}$ & $\begin{array}{l}\text { - } \quad \text { nowa służebna rola policji względem obywateli; } \\
\text { - } \quad \text { weryfikacja funkcjonariuszy sprzed } 1990 \text { roku; } \\
\text { - } \\
\text { - }\end{array}$ \\
\hline $\begin{array}{l}\text { Transformacja, } \\
\text { organizacja, } \\
\text { system dowodzenia } \\
\text { i kierowania } \\
\text { siłami zbrojnymi }\end{array}$ & $\begin{array}{ll}\text { - } & \text { cywilna kontrola nad armią jako warunek } \\
& \text { funkcjonowania armii w demokratycznym państwie } \\
& \text { dążącym do członkostwa w NATO; } \\
\text { - } & \text { system dowodzenia Siłami Zbrojnymi RP; } \\
- & \text { uzawodowienie i zawieszenie powszechnego poboru; } \\
\text { - } & \text { obrona terytorialna i system szkolenia rezerw; } \\
- & \text { zaangażowanie wojsk polskich poza granicami } \\
& \text { państwa - skala, priorytety, relacja do obowiązku } \\
& \text { zapewniania bezpieczeństwa granic państwa. }\end{array}$ \\
\hline $\begin{array}{c}\text { Transformacja } \\
\text { i organizacja } \\
\text { wymiaru sprawiedliwości }\end{array}$ & $\begin{array}{l}\text { - } \quad \text { zaostrzenie/liberalizacja kar za przestępstwa, } \\
\text { nieuchronność kary; } \\
\text { - } \\
\text { - } \\
\text { stosunek do kary śmierci; } \\
\text { - } \quad \text { nadzór ministra sprawiedliwości nad pracą sądów } \\
\quad \text { i prokuratur; } \\
\text { - } \quad \text { przewlekłość postępowań sądowych. }\end{array}$ \\
\hline $\begin{array}{l}\text { Bezpieczeństwa } \\
\text { sektorowe }\end{array}$ & $\begin{array}{l}\text { - } \quad \text { ekonomiczne (gospodarcze); } \\
\text { - energetyczne; } \\
\text { - } \text { społeczne; } \\
\text { - } \text { zdrowotne; } \\
\text { - } \quad \text { środowiskowe. }\end{array}$ \\
\hline $\begin{array}{c}\text { Zarządzanie } \\
\text { kryzysowe }\end{array}$ & $\begin{array}{l}\text { - } \quad \text { organizacja systemu zarządzania kryzysowego } \\
\text { na wszystkich szczeblach działania państwa; } \\
\text { - } \quad \text { obrona cywilna. }\end{array}$ \\
\hline $\begin{array}{c}\text { Polityka } \\
\text { migracyjna }\end{array}$ & $\begin{array}{l}\text { - } \quad \text { stosunek do Polaków poza granicami państwa, } \\
\text { w szczególności na wschodzie; } \\
\text { - } \quad \text { polityka wobec imigrantów zarobkowych; } \\
\text { - } \quad \text { polityka wobec uchodźców. }\end{array}$ \\
\hline $\begin{array}{c}\text { Terroryzm } \\
\text { i jego zwalczanie }\end{array}$ & $\begin{array}{l}\text { - zaangażowanie w działania poza granicami państwa; } \\
\text { - ustawa antyterrorystyczna. }\end{array}$ \\
\hline
\end{tabular}

Źródło: opracowanie własne. 
Aby dokonać jakościowej analizy prezentowanych zagadnień, badany okres lat 1989-2015 podzielony został na trzy przedziały czasowe. Zaprezentowano je w tabeli 4, wraz ze wskazaniem głównych kwestii i podejścia do nich sił politycznych.

Tabela 4. Podział czasowy badanego okresu

\begin{tabular}{|c|c|}
\hline $\begin{array}{l}\text { Przedział } \\
\text { czasowy }\end{array}$ & $\begin{array}{l}\text { Charakterystyka okresu - treści szczegółowe pojawiające się } \\
\text { w programach wyborczych }\end{array}$ \\
\hline 1989-1999 & $\begin{array}{l}\text { okres transformacji i budowy systemu bezpieczeństwa } \\
\text { w nowym ustroju państwa } \\
\text { (nowa konstytucja, ustawa o dziatach administracji, uporządkowanie } \\
\text { organizacyjne formacji zapewniających bezpieczeństwo państwa, dostosowanie } \\
\text { funkcjonowania armii do wymogów NATO-wskich) } \\
\text { - cywilna kontrola nad armią i system jej dowodzenia; stopniowe } \\
\text { uzawodowienie Sił Zbrojnych (skracanie służby wojskowej } \\
\text { w ramach powszechnego obowiązku); } \\
\text { - podział organizacyjny policji (piony prewencji, kryminalne etc.) } \\
\text { i jej wyposażenie, system rekrutacji, finansowanie policji; } \\
\text { - zaostrzenie kar za przestępstwa ciężkie oraz za korupcję; } \\
\text { - budowa systemu zwalczania przestępczości zorganizowanej; } \\
\text { - ocena reform gospodarczych w kontekście bezpieczeństwa państwa } \\
\text { (np. obcy kapitał) i bezpieczeństwa jednostek (finanse gospodarstw } \\
\text { domowych, bezrobocie); } \\
\text { - bezpieczeństwo zdrowotne - reforma systemu ubezpieczeń zdrowotnych, } \\
\text { ocena Kas Chorych w kontekście zapewniania bezpieczeństwa } \\
\text { zdrowotnego; } \\
\text { - bezpieczeństwo energetyczne (kontekst węgla jako surowca do jego } \\
\text { zapewniania). }\end{array}$ \\
\hline 2000-2013 & $\begin{array}{l}\text { okres adaptacji } \\
\text { (dostosowanie do wyzwań, procedur UE, reagowanie kryzysowe poza granicami } \\
\text { kraju, skupienie na zagrożeniach wewnętrznych - przestępczość, korupcja) } \\
\text { - } \quad \text { armia zawodowa ekspedycyjna; } \\
\text { - } \quad \text { strategia obrony kolektywnej; } \\
\text { - } \quad \text { walka z przestępczością (w tym zorganizowaną) i korupcją jako główne } \\
\quad \text { wyzwanie dla policji, powstanie CBŚ; } \\
\text { - } \quad \text { reforma wymiaru sprawiedliwości pod kątem usprawnienia jego } \\
\quad \text { działania (przewlekłość postępowań, stosowanie prawa); } \\
\text { - bezpieczeństwo energetyczne jako wyzwanie strategiczne (gazoport } \\
\quad \text { LNG w Świnoujściu, inne plany dywersyfikacji dostaw surowców, } \\
\text { Gazociąg Północny jako zagrożenie dla bezpieczeństwa energetycznego } \\
\text { RP); } \\
\text { - bezpieczeństwo ekonomiczne; } \\
\text { - bezpieczeństwo środowiskowe; } \\
\text { - bezpieczeństwo zdrowotne w kontekście reformy służby zdrowia (Kasy } \\
\text { Chorych a NFZ). }\end{array}$ \\
\hline
\end{tabular}


Tab. $4-\mathrm{cd}$.

\begin{tabular}{|c|c|}
\hline Od 2014 & $\begin{array}{l}\text { okres zmiany priorytetyzacji zagrożeń } \\
\text { (zmiana w postrzeganiu zagrożeń: cyberprzestrzeń, atak na terytorium RP, } \\
\text { terroryzm islamski, budowa nowych formacji obronnych) } \\
\text { - } \quad \text { armia do obrony terytorium kraju. Powstanie Wojsk Obrony } \\
\text { Terytorialnej. Kolejna reforma systemu dowodzenia; } \\
\text { - } \quad \text { prewencyjna rola policji (mapy zagrożeń, dzielnicowi); } \\
\text { - } \quad \text { bezpieczeństwo migracyjne w kontekście zagrożeń powodowanych przez } \\
\text { potencjalnych uchodźców (terroryzm, zagrożenia epidemiologiczne) } \\
\text { oraz w kontekście zagrożeń dla Polaków poza granicami kraju (skutki } \\
\text { Brexitu), a także imigrantów zarobkowych w Polsce (Ukraińcy, } \\
\text { Białorusini, Wietnamczycy); } \\
\text { - cyberzagrożenia jako istotna dziedzina zagrożeń dla bezpieczeństwa RP; } \\
\text { - nowe rozwiązania w systemie zwalczania terroryzmu (ustawa } \\
\text { antyterrorystyczna); } \\
\text { - reforma wymiaru sprawiedliwości w kontekście jego usprawnienia; } \\
\text { - bezpieczeństwo zdrowotne w kontekście wciąż niezadowalającej jakości } \\
\text { publicznych usług medycznych; } \\
\text { - bezpieczeństwo środowiskowe. }\end{array}$ \\
\hline
\end{tabular}

Źródło: opracowanie własne.

Jak wspomniano we wprowadzeniu do tabeli, analiza treści programów partii politycznych w zakresie bezpieczeństwa wewnętrznego miała przede wszystkim charakter jakościowy. Podejście takie było celowe i zamierzone: cytowany już M. Cześnik, który próbował analizować programy partyjne metodami ilościowymi, przyznaje, że trudności z kodowaniem zmiennych, brak możliwości uwzględnienia kontekstu, w jakich pojawiają się zmienne, o subtelnościach językowych nie wspominając, mogą w niektórych przypadkach dawać mylne wyniki (Cześnik, 2011). R. Markowski uważa wręcz, że właśnie ten brak kontekstu czyni z badań ilościowych (MRG) metodę „właściwie bezwartościową” (Markowski, 2002).

Jakościowa analiza treści programów wyborczych pozwala stwierdzić, że kwestie związane z bezpieczeństwem i porządkiem publicznym nabierają priorytetowego znaczenia dopiero w wyborach w drugiej dekadzie XXI wieku. Pierwsza dekada analizowanego okresu to przede wszystkim programy oparte w głównej mierze na zagadnieniach gospodarczych. Przyznać trzeba, że czasami w tym kontekście twórcy programów mówią o bezpieczeństwie ekonomicznym, mając na myśli głównie perspektywę personalną - bezpieczeństwo gospodarstw domowych, ale przede wszystkim skupiają się na wyzwaniach transformacji gospodarczej kraju. Stąd też wątek bezpieczeństwa energetycznego, który w latach późniejszych będzie rozpatrywany w kontekście dywersyfikacji źródeł energii i alternatywnych tras dostaw, w latach 90. XX wieku widziany jest w kontekście węgla jako pod- 
stawowego surowca energetycznego i zamykanych nierentownych kopalń. Ekonomia dominuje programy wyborcze wszystkich partii, choć jest to przecież czas tworzenia podstaw prawnych funkcjonowania formacji mundurowych w Polsce oraz Sił Zbrojnych z cywilnym zwierzchnictwem. Policja zyskuje nową, służebną wobec obywatela rolę, problemem jest jej chroniczne niedofinansowanie oraz wynikające z niego braki kadrowe i sprzętowe, i to w czasie, gdy przychodzi się jej zmierzyć ze zorganizowaną przestępczością, niezwykle dynamicznie rozwijającą się w okresie transformacji. W programach partii politycznych można znaleźć odwołania do tych kwestii, ale nie zajmują one ani wysokiej pozycji, ani dużo miejsca. Nawet czołowe obecne w parlamencie ugrupowania, jak np. SLD, w wygranych przez siebie wyborach z 1993 roku w ogóle się do tych kwestii nie odwołują (Słodkowska, 2001). Często pojawia się natomiast pojęcie bezpieczeństwa społecznego (w kontekście realizowanych reform gospodarczych) oraz zdrowotnego (w kontekście reformy publicznej służby zdrowia). Można więc stwierdzić, że choć okres transformacji i budowy systemu bezpieczeństwa w nowym ustroju państwa obfitował w działania na lata determinujące strategie zapewniania bezpieczeństwa i funkcjonowanie odpowiedzialnych za to instytucji, w programach partii politycznych omawianego okresu trudno znaleźć potwierdzenie istotności tych wydarzeń w postaci podnoszenia i priorytetyzacji tych kwestii. Dominacja kwestii ekonomicznych jest tak silna, że nawet kwestia wejścia Polski do NATO - najważniejsze zagadnienie z zakresu bezpieczeństwa strategicznego dekady 1989-1999, w dokumentach partyjnych tego okresu najczęściej jest zbywane jednym zdaniem, a w wielu programach nie pojawia się wcale.

Drugi z omawianych okresów - lata 2000-2013, nazwane czasem adaptacji, to $\mathrm{w}$ głównej mierze dostosowywanie polskich przepisów prawnych i praktyki ich stosowania oraz postępowania do wymogów Unii Europejskiej. Proces negocjacyjny oraz implementacja procedur trwająca także już po podpisaniu Traktatu Akcesyjnego w 2003 roku wywierały wpływ również na kwestie bezpieczeństwa wewnętrznego, chociażby co do systemu ochrony granic (znowelizowana w 2001 roku ustawa o Straży Granicznej dostosowała uprawnienia tej formacji do wymogów strefy Schengen). Był to też czas kluczowych decyzji w obszarze organizacji formacji przeznaczonych do zapewniania bezpieczeństwa: zapadła decyzja o stopniowym pełnym uzawodowieniu armii, która w omawianym czasie realizowała głównie zadania ekspedycyjne (operacje poza granicami kraju), z jednoczesnym postulatem stworzenia systemu szkolenia rezerw bądź wojsk typu OT, w Policji stworzono struktury do zwalczania przestępczości zorganizowanej (CBŚ, dziś: CBŚP), służbę zdrowia dotknęła kolejna reforma systemowa mająca zapewnić wyższy poziom bezpieczeństwa zd rowotnego, wysoki priorytet zyskało bezpie- 
czeństwo energetyczne (szukanie źródeł dywersyfikacji surowców energetycznych, w tym budowa terminalu LNG w Świnoujściu, protesty przeciwko planom i budowie Gazociągu Północnego). Jest to również czas budowy systemu zarządzania kryzysowego (w oparciu na ustawie z 2007 roku). Wszystkie te kwestie są obecne w programach partii politycznych, ale podobnie jak w przypadku pierwszego omawianego okresu, nie zajmują szczególnie istotnego miejsca. Platforma Obywatelska do wygranych przez siebie wyborów z 2007 i 2011 roku szła z programami, w których obecne były jedynie kwestie bezpieczeństwa energetycznego.

W ostatnim, najkrótszym okresie, nazwanym: zmiany priorytetyzacji zagrożeń, którego początek datowano na 2014 rok i kampanie przed wyborami prezydenckimi i parlamentarnymi z 2015 roku, obserwować można zdecydowaną zmianę podejścia nie tylko do samych kwestii bezpieczeństwa, które zaczynają zajmować istotną pozycję w programach partii politycznych, ale również co do rodzaju i skali kluczowych zagrożeń i propozycji co do ich zwalczania. Nie tylko ważnym punktem programów w wyborach z 2015 roku, ale wręcz osią kampanijnego dyskursu była kwestia przyjmowania uchodźców, w ramach relokacji z obozów w innych krajach Unii Europejskiej. Drugim istotnym wątkiem był zgłoszony przez PiS pomysł wzmocnienia potencjału obronnego państwa przez tworzenie Wojsk Obrony Terytorialnej, który stał się elementem szerszej dyskusji o zmianie podejścia co do sposobu użycia Sił Zbrojnych. Trzecim istotnym elementem było bezpieczeństwo antyterrorystyczne i zapowiedź uchwalenia ustawy ujednolicającej i usprawniającej działania służb w tym zakresie. W programach dalej obecna jest, choć w zdecydowanie mniejszym wymiarze niż we wcześniejszym okresie, problematyka bezpieczeństwa energetycznego, demograficznego, ekonomiczno-społecznego (program 500+ bywał interpretowany w tym kontekście).

\section{Zakończenie}

Prezentowane $\mathrm{w}$ artykule wnioski z badań programów wyborczych partii i kandydatów pod kątem zagadnień z zakresu bezpieczeństwa wewnętrznego pokazują, że wbrew potocznym oczekiwaniom zagadnienia te przez większość badanego okresu nie stanowiły istotnej części partyjnych programów. Pierwsze 10 lat po 1989 roku to bezpieczeństwo widziane przede wszystkim z punktu widzenia ekonomicznego bezpieczeństwa jednostek oraz walka z przestępczością, w tym zorganizowaną. Drugi badany okres to czas adaptacji do wymogów i standardów UE, i również nie jest to czas, w którym tematyka bezpieczeństwa zajmuje istotne miejsce w programach polskich partii politycznych. Zmianę w tym zakresie widać od 
2014 roku, w tym w szczególności w dwóch kampaniach z roku 2015. Tematy takie jak kryzys migracyjny, zagrożenie dla bezpieczeństwa Polski w związku z konfliktem na Ukrainie czy bezpieczeństwo ekonomiczno-społeczne zdominowały te kampanie i z dużym prawdopodobieństwem będą obecne również w przyszłych programach wyborczych.

\section{Bibliografia:}

Ciszek, M. (2011). Teoretyczne podstawy bezpieczeństwa państwa. Prosopon, Europejskie Studia Spoteczno-Humanistyczne, 2, 165-174.

Czaputowicz, J. (2014). Ewolucja polskiej polityki bezpieczeństwa: w kierunku strategicznej samodzielności? Studia Politologiczne, 34, 15-31.

Czaputowicz, J. (2013). Polityka bezpieczeństwa Polski - między samodzielnością a europeizacją. E-Politikon, 4, 24-41.

Cześnik, M. (2011). Zawartość programów polskich partii politycznych - zastosowanie metody MRG do ilościowej analizy treści. W: I. Słodkowska, M. Dołbakowska (red.), Wybory 2007. Partie i ich programy. Warszawa: ISP PAN.

Fiszer, J.M. (2011). Bilans pierwszych lat członkostwa Polski w Unii Europejskiej. Warszawa: ISP PAN.

Fiszer, J.M. (2009). Polska w Unii Europejskiej. Aspekty polityczne, międzynarodowe, spoteczno-gospodarcze i wojskowe. Warszawa: ISP PAN.

Fiszer, J.M. (2006). Polska polityka integracyjna po przystapieniu do Unii Europejskiej. Warszawa: ISP PAN.

Fleischner, J., von Hippel, K., Barton, F. (2009). Homebound, Security, Migrant Support for Improved Public Safety in Conflict-Prone Settings. A Report of the CSIS Post-Conflict Reconstruction Project. Centre for Strategic and International Studies.

Markowski, R. (2002). Propozycja MRG: metoda, wyniki, problemy - komentarz. W: R. Markowski (red.), System partyjny i zachowania wyborcze. Dekada polskich doświadczeń. Warszawa: ISP PAN, Fundacja im. Friedricha Eberta.

Koziej, S. (1996). Bezpieczeństwo narodowe i obronność Rzeczypospolitej Polskiej. Toruń: Wydawnictwo Adam Marszałek.

Koziej, S. (2006). Między piektem a rajem. Szare bezpieczeństwo na progu XXI wieku. Toruń: Wydawnictwo Adam Marszałek.

Koziej, S. (2005). Strategiczne problemy bezpieczeństwa globalnego i euroatlantyckiego. Warszawa: Wydawnictwo AON.

Koziej, S. (2009). Polskie interesy w nowej koncepcji strategicznej Organizacji Traktatu Pótnocnoatlantyckiego. Toruń: Wydawnictwo Adam Marszałek.

Kukułka, J. (2001). Kształtowanie się nowego ładu międzynarodowego w latach 90. W: Świat po „zimnej wojnie”. Warszawa: Instytut Problemów Bezpieczeństwa.

Kupiecki, R. (red.). (2015). Obrona przeciwrakietowa w polskiej perspektywie. Warszawa: PISM. Kupiecki, R. (2014). Akcesja Polski do NATO - okiem historyka i uczestnika. Bezpieczeństwo Narodowe, 29, 41-76. 
Linz, J.J., Stepan, A. (1996). Problems of Democratic Transition and Consolidation. Southern Europe, South America and Post-Communist Europe. Baltimore-London: The Hopkins University Press.

Majer, P. (2012). W poszukiwaniu uniwersalnej definicji bezpieczeństwa wewnętrznego. Przeglad Bezpieczeństwa Wewnętrznego, 7.

Raciborski, J. (2013). Wybory 2011 - uwagi o instytucjonalnych uwarunkowaniach zachowań wyborczych. W: Wybory 2011. Partie i ich programy. Warszawa: ISP PAN.

Rutkowski, C. (2010). Bezpieczeństwo wewnętrzne. Tożsamość-kierowanie-zarządzanie. Warszawa: Wyższa Szkoła Zarządzania i Prawa w Warszawie.

Sekściński, A. (2013). Bezpieczeństwo wewnętrzne w ujęciu teoretycznym. Geneza i współczesne rozumienie w naukach politycznych. E-Politikon, 6, 42-79.

Słodkowska, I. (red.). (2001). Wybory 1993. Partie i ich programy. Warszawa: ISP PAN.

Słodkowska, I., Dołbakowska, M. (red.). (2004). Wybory 1997. Partie i ich programy. Warszawa: ISP PAN.

Stownik podstawowych terminów bezpieczeństwa państwa. (1994). Warszawa: Akademia Obrony Narodowej.

Smith, D. (2006). Crisis Management - Practice in Search of a Paradigm. W: D. Smith, D. Elliott (red.), Crisis Management. Systems and Structures for Prevention and Recovery. London-New York: Routledge.

Strategia Bezpieczeństwa Narodowego. (2014). Pobrane z: https://www.bbn.gov.pl/ftp/ SBN\%20RP.pdf.

Strategia bezpieczeństwa wewnętrznego Unii Europejskiej. Dążąc do europejskiego modelu Bezpieczeństwa. (2010). Pobrane z: http://www.consilium.europa.eu/media/30744/qc3010313 plc.pdf.

Sulowski, S. (2011). O nowym paradygmacie bezpieczeństwa w erze globalizacji. W: S. Sulowski, M. Brzeziński, Bezpieczeństwo wewnętrzne państwa. Wybrane zagadnienia. Warszawa: Dom Wydawniczy Elipsa.

Wawrzyk, P. (2009). Bezpieczeństwo wewnętrzne w Unii Europejskiej. Warszawa: Wydawnictwa Akademickie i Profesjonalne.

Wojtaszczyk, K.A. (2009). Istota i dylematy bezpieczeństwa wewnętrznego. W: Przegląd Bezpieczeństwa Wewnętrznego, 1.

Zaborowski, J. (1985). Administracyjnoprawne ujęcie pojęć bezpieczeństwo publiczne i porządek publiczny. Zeszyty Naukowe ASW, 41.

Zięba, R. (2010). Polityka zagraniczna Polski w strefie euroatlantyckiej. Warszawa: Wydawnictwa Uniwersytetu Warszawskiego.

Zięba, R. (2004). Instytucjonalizacja bezpieczeństwa europejskiego: koncepcje - struktury - funkcjonowanie. Warszawa: Scholar.

Zięba, R. (red.). (1997). Bezpieczeństwo narodowe i międzynarodowe u schytku XX wieku. Warszawa: Scholar.

Zięba, R. (2013). Bezpieczeństwo w polityce zagranicznej RP rządu koalicji Platformy Obywatelskiej i Polskiego Stronnictwa Ludowego. Stosunki Międzynarodowe - International Relations, 47, 1-2, 9-33.

Ziółkowski, M. (2000). Przemiany interesów i wartości społeczeństwa polskiego. Poznań: Wydawnictwo Fundacji Humaniora. 